\title{
ANALYSIS OF FACTORS AND MANAGEMENT OF HEPATITIS B VIRUS SCREENING IN MOTHERS AND INFANTS: A SCOPING REVIEW
}

\author{
Setianingsih, Nurul Kurniati \\ Universitas ‘Aisyiyah Yogyakarta
}

\begin{abstract}
Background: The importance of screening for HBV infection is to identify the risk of perinatal transmission from infected mothers. People infected with HBV during infancy or childhood are more likely to suffer chronic infection to cirrhosis of the liver and liver cancer. Early detection and prompt treatment are essential for HBV infection. This study aimed to review the factors and management of hepatitis B virus screening in mothers and infants.

Subjects and Method: A scoping review method was conducted in eight stages including (1) Identification of study problems; (2) Determining priority problem and study question; (3) Determining framework; (4) Literature searching; (5) Article selection; (6) Critical appraisal; (7) Data extraction; and (8) Mapping. The search included PubMed, ScienceDirect, Wiley Online Library, and Scopus databases. The inclusion criteria were English/ Indonesian-language and full-text articles (scoping review, meta-analysis, systematic review)/ documents/ reports/ policy brief/ guidelines from WHO/ other organizations published between 2009 and 2019. The data were selected by the PRISMA flow chart.

Results: The searched database obtained a total of 27.862 articles. After screening, 27.325 articles were excluded because of unmet the inclusion criteria. After conducting critical appraisal for the remaining 537 articles, only 11 articles were eligible for further review. The selected articles obtained from developing countries (China, South Africa, and Tanzania) and developed countries (Netherlands, Japan, Denmark, Northern Europe, and Canada) with quantitative studies design (cross-sectional, case series, and cohort) met the inclusion criteria. The findings emphasized on four main topics around hepatitis B virus screening in mothers and infants, namely demographic factors, risk factors, post-screening benefit, and challenges in screening uptake.

Conclusion: Early detection of HBV infection with prenatal screening reduce the HBV prenatal transmission, especially from infected pregnancy. Screening plays an important role in the administration of universal infant HBV vaccination and postexposure prophylaxis with hepatitis B immune globulin (HBIG) at birth.
\end{abstract}

Keywords: pregnant women, hepatitis B virus, perinatal transmission, screening

\section{Correspondence:}

Setianingsih. Universitas 'Aisyiyah Yogyakarta. Jl. Siliwangi (Ringroad Barat) No. 63, Nogotirto, Gamping, Sleman, Yogyakarta, 55292. Email: nsetia580@gmail.com. Mobile: 082242081295.

The $7^{\text {th }}$ International Conference on Public Health Solo, Indonesia, November 18-19, 2020 | 247 https://doi.org/10.26911/the7thicph.03.67 